\title{
Neuropile Organization in the Brain of Acromyrmex (Hymenoptera, Formicidae) during the Post-Embryonic Development
}

\author{
Paula Andréa Oliveira Soares ${ }^{1}$, Jacques Hubert Charles Delabie ${ }^{2}$ and José Eduardo \\ Serrão $^{3 *}$ \\ ${ }^{1}$ Departamento de Biologia Animal; Universidade Federal de Viçosa; 36571 -000; Viçosa-MG - Brazil. ${ }^{2}$ U. P. A. \\ Laboratório de Mirmecologia; Convênio UESC/CEPLAC; C. P. 07; 45600-000; Itabuna - BA - Brazil. ${ }^{3}$ Departamento \\ de Biologia Geral; Universidade Federal de Viçosa; 36571-000; jeserrao@ufv.br; Viçosa - MG - Brazil
}

\begin{abstract}
Neuropile is the region of the central nervous system where the synapses and neurons branching occur. During the development of an holometabolous insect can occurs break of the neurons fibers forming new axon and dendrites and their distribution in brain neuropile is organized so as to reflect specific nervous functions of adult insects. The components of this organization were observed and discussed in this study in the ant Acromyrmex octospinosus,

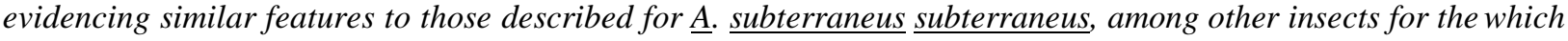
ones this information is available.
\end{abstract}

Key words: Neuropile, nervous system, ant, neuronal reorganization

\section{INTRODUCTION}

In the nervous system of holometabolous insects, neuroblasts proliferate during larval stage and their offspring differentiates in other neurons during the transition larvae/pupae. These neurons die by programmed cell death, or suffer morphologic and synaptic reorganization acquiring new features for adult life (Levine and Truman, 1982). Neuropile is the central region of the ganglia where the majority of synapses occurs and the reorganization along the insect development can occur by means of break of the fibers of the Kenyon cells, which would form then new connections (Technau, 1984). The pattern of neural reorganization during the post-embryonic development was described in some insects species such as in the ants
Pachycondyla caffraria (Masson, 1970), Acromyrmex octospinosus (Delabie et al., 1986) and A. subterraneus subterraneus (Soares and Serrão, 2001a), in Drosophila melanogaster (Technau and Heisenberg, 1982), Manduca sexta (Levine and Truman, 1982) and Apis mellifera (Vitt and Hartfelder, 1998). Although some brain structures of the insects are distinguished since the larval stage, because they have the same location and orientation than in the adult insect (Technau and Heisenberg, 1982; Soares and Serrão, 2001a), in the end of pupal stage the neuropile is the larger part of the brain, while the area occupied by Kenyon cells decreases (Soares and Serrão, 2001a). Through the utilization of the histochemical procedures using Cobalt Chloride, we describe the neuropile organization in the brain of Acromyrmex

\footnotetext{
* Author for correspondence
} 
octospinosus during the post-embryonic development, in order to contribute to a better comprehension of the growth pattern neuron branching.

\section{MATERIAL AND METHODS}

Ants were collected in nests of A. octospinosus in Guadeloupe (French Antilles) and maintained at 25-30 ${ }^{\circ} \mathrm{C}$. The experiments were made in Station de Zoologie of the Centers of Recherche Agronomique des Antilles et de la Guyane (I.N.R.A.) in Petit Bourg (Guadeloupe) and in the Laboratoire de Neurobiologie Sensorielle de l'Insecte I.N.R.A/C.N.R.S. in Bures sur Yvette (France). Ants from pupae until newly emerged adult were analyzed and age classified according to the color of the eyes: unpigmented eyed, pink eyed, brown eyed and black eyed pupae and adult. For Cobalt Chloride histochemical test (Pitman et al, 1972, 1973) one antennal edge was cut out and the Cobalt Chloride solution applied with a microcapillary pipette for 12 hours. After this period, the brain was dissected and transferred to alcoholic Bouin, following standard procedures for paraffin embedding tissues. Brains were cut at 7 $\mu \mathrm{m}$ thick cobalt staining showed by silver nitrate precipitation, followed by the Timm's staining. This procedure show those neurons related with the antennal activity. Changes in brain anatomy during the post-embryonic development were obtained in A. subterraneus subterraneus from nests in the Insetary of the Federal University of Viçosa, Minas Gerais, Brazil. Brains of ants with the same ages analyzed above were removed, analyzed and schematized under stereomicroscope. These anatomical aspects were compared with morphometric data for this ant species obtained by Soares and Serrão (2001b), which had the same age of A. octospinosus determined by Delabie (1984).

\section{RESULTS AND DISCUSSION}

\section{a) Neuropile differentiation}

In the early pupal stage of A. octospinosus axon endings from sensory neurons (afferent) begin to colonize the neuropile of the antennal lobe just after the antennal imaginal disc eversion. In the antennal nerve organization, two principal branches were seen in the unpigmented eyed pupae and the antennal lobe neuropile was represented by an undifferentiated structure in this pupal stage. Between brown and black eyed pupae a continuous growth of the antennal nerve occur (Fig. 8). The axon from sensory neurons and the antennal lobe neuropile gradually reached to deutocerebrum. At end of the pink eyed pupae, the periphery of antennal lobe neuropile was differentiated in preglomerulli, while in the middle region, neuropile remains an undifferentiated structure (Fig. 1). Arnold and Masson (1983) observed similar results in Apis mellifera. In the brown eyed pupae, preglomerulli population extended to whole neuropile and in the black eyed ones the general organization of the antennal neuropile was the sames of the adult (Figs. 6, 8). In all studied developmental stages, the general aspect of the brain of $A$. octospinosus showed similar characteristics to those found in $A$. subterraneus subterraneus described by Soares and Serrão (2001a). Kenyon cells occupied most brain cortex and in the concentric regions of the calyx of corpora pedunculata neuroblasts in division could be seen (Fig. 1). The neuropile, strongly positive to the Cobalt Chloride, form thick bundles arisen from axon and dendrites of the neurons distributed by the whole brain: Kenyon cells of corpora pedunculata extended their dendrites inside the calyx and their axons dispose along peduncle where they were divided in two branches forming the $\alpha$ and $\beta$ lobes. In peduncles and lobes, Kenyon cells showed synapses with dendrites of the extrinsic neurons (neurons with axons that extended to different brain areas) (Mizunami et al., 1998; Gronenberg and Hölldobler, 1999). In pink eyed pupae, can be found the corpora pedunculata peduncles with the junction area of the lobes $\alpha$ and $\beta$, was observed here due to the tangential section of the brain (Fig. 2 and 3). The neuropile of the optical lobes (lobula and medulla), except the lamina were also present in this developmental stage (Fig. 1). In brown eyed pupae, brain showed different shape and neuropile extended to the protocerebrum and deutocerebrum. Hence, other brain regions such as $\beta$ lobe, central body complex with the superior arch and the fanshaped body could distinguished (Figs. 3 and 4). This central region of the brain consisted of four parts: the protocerebral bridge, the superior division and inferior of the central body [homologous to the ellipsoid body, described in some insects by Hanesch et al. (1989) and paired 
nodulli that were interconnected by small group of interneurons and large groups that covered the protocerebrum (Burrows, 1996). Different terminologies are adopted according to the insect group (Homberg, 1987). In Drosophila two other components of the central body complex, the fanshaped body and the superior arch were suggested, which constituted a neuropile layer located above of the fan-shaped body (Hanesch et al., 1989). In Acromyrmex, the complete recognition of these structures occured from brown eyed pupae, because in the previous pupal stages the central body complex was represented by an undifferentiated mass of neuropile. All the components of the central body complex described above have been found in various insect species (Hanesch et al., 1989). Jaffé and Perez (1989) have pointed out that in Attini ants the central body, the protocerebral bridge and the corpora pedunculata calyx have greater volume in adult major worker than minor and middle workers of $A$. octospinosus.
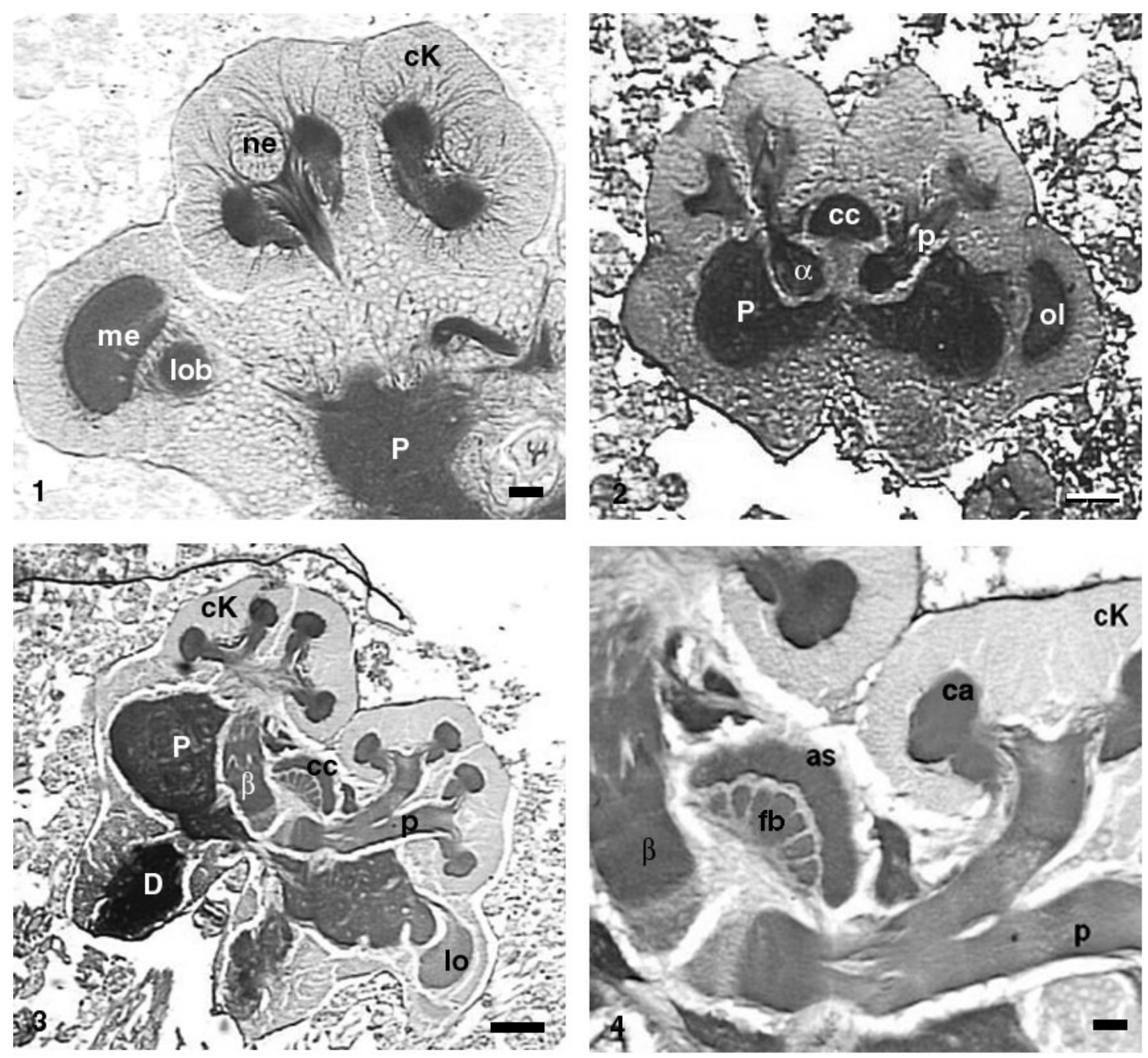

Figures 1- 4 - Longitudinal section in the brain of pupae of Acromyrmex octospinosus showing neuropile regions and your constituent cells. Figures 1-2 - Pink Eyed Pupae; 3-4 - Brown Eyed Pupae, medulla (me), lobula (lob), neuroblasts (ne), Kenyon cells (cK), protocerebrum's neuropile (P), central body complex (cc), peduncule (p), optical lobe (ol), $\alpha$ lobes $(\alpha), \beta$ lobes $(\beta)$, deutocerebrum's neuropile (D), superior arch (sa), fan-shaped body (fb), calyx(ca). Bars $=$ Bars $=20 \mu \mathrm{m}$. 

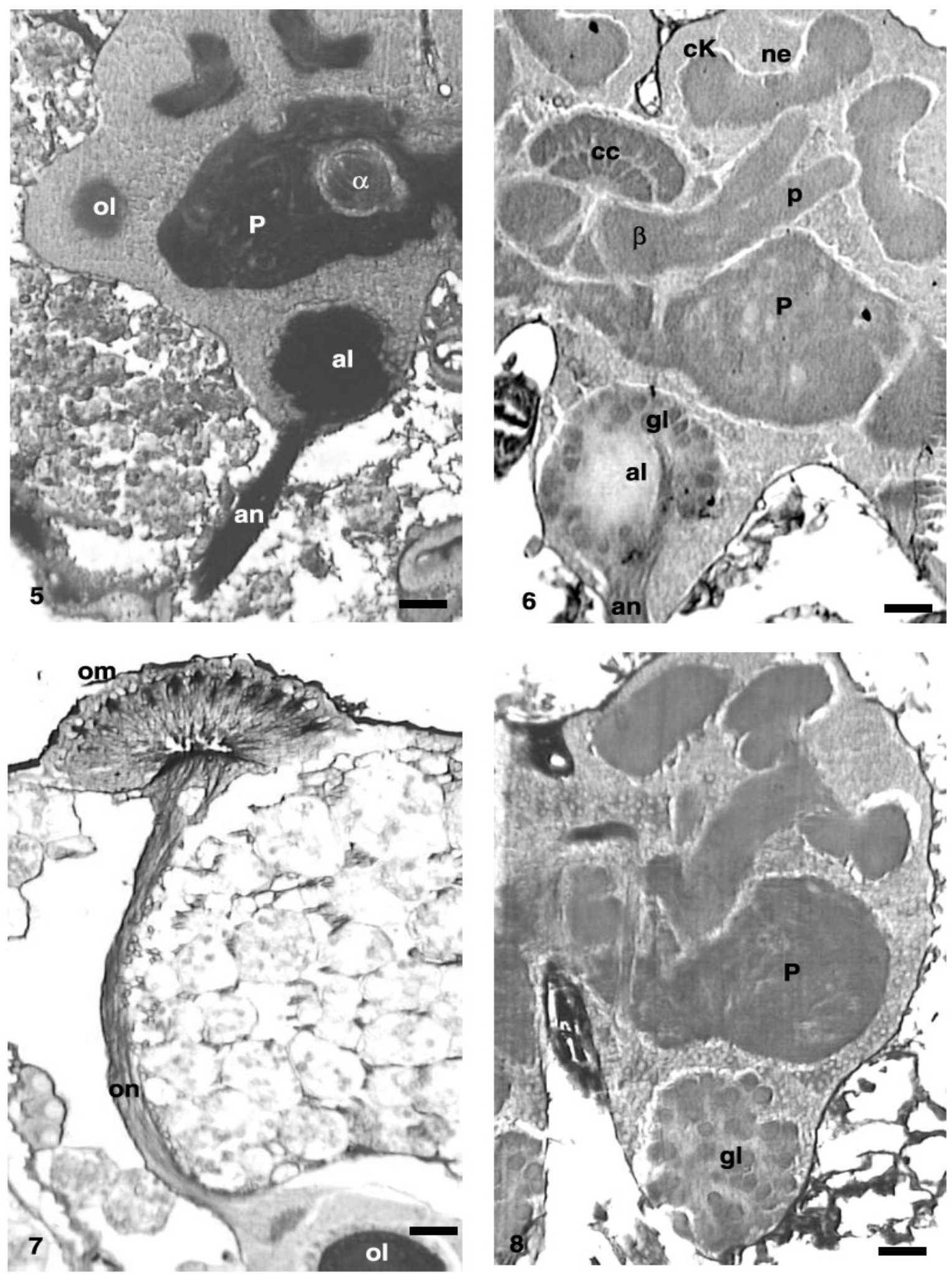

Figures 5 - 8 - Longitudinal section in the brain of Acromyrmex octospinosus and your neuropilars compartments. Figure 5 - Brown Eyed Pupae - optical lobe (ol), $\alpha$ lobes $(\alpha)$, Protocerebrum's neuropile $(\mathrm{P})$, antennal lobe (al), antennal nerve (an); Figure 6-7 - Black Eyed Pupae - neuroblasts (ne), Kenyon cells $(\mathrm{cK})$, central body complex (cc), peduncule (p), $\beta$ lobes $(\beta)$, glomerulli (gl), ommatides (om), optical nerve (on); Figure 8 - Adult - protocerebrum's neuropile (P), glomerulli (gl). Bars $=20 \mu \mathrm{m}$. 


\begin{tabular}{|c|c|c|c|c|}
\hline $\begin{array}{c}\text { Frontal View of the Brain } \\
* \text { Soares e Serrão (2001) } * * \text { Delabie (1984) }\end{array}$ & $\begin{array}{c}\text { Eyes } \\
\text { Pigmentation* }\end{array}$ & Area $\left(\mathbf{m m}^{2}\right)^{*}$ & $\begin{array}{c}\text { Volume }\left(\mathbf{m m}^{2}\right) \\
\times 10^{-7 *}\end{array}$ & Life Days** \\
\hline & UE & 0,376 & 5,1 & $<1$ \\
\hline & $\mathrm{PE}$ & 0,386 & 5,0 & 1 a 2 \\
\hline & BRE & 0,442 & 4,5 & 3 \\
\hline & BLE & 0,431 & 4,8 & 6 \\
\hline & $\mathrm{AD}$ & 0,505 & 6,5 & $>25$ dias \\
\hline
\end{tabular}

Figure 9 - Morphologic and morphometrics relationships in two species of Acromyrmex in accord with pigmentation of eyes during the post-embryonic development. Unpigmented Eyed (UE), Pink Eyed (PE), Brown Eyed (BRE), Black Eyed (BLE) and Adult (AD). Arrows indicate concentric regions with rate high of neuroblasts division in individuals with brown eyed.

\section{b) Neuropile maturation}

In brown eyed pupae, we observed the $\alpha$ lobes and part of the antennal nerve that reached the antennal lobe (Fig. 5). Antennal lobes constituted neuropile regions, inside of which there were small areas of dense synaptic neuropiles that in some insects were lined by a layer of glial cells. These structures were termed glomerulli and were evidenced only from black eyed pupae, where they were grouped on periphery of the lobe (Figs. 6, 8). Among species, glomerulli were constant in the shape and position (Chapman, 1998). In each axon of the sensory sensillum from antenna ending in a glomerulli or in a glomerulli group (Masson,
1970), were the connections among sensory neurons and deutoneurons (Hanson et al., 1992; Christensen et al., 1995), where few efferent deutoneurons and local interneurons were found. The main association region, where the synapses were established, was the glomerulli periphery termed "glomerular cortical layer" in several Hymenoptera studied (Masson, 1970; Delabie, 1984; Fonta, 1984). Presumably, the information arising of the antenna was grouped, integrated and amplified in the glomerulli level before being transmitted to the association centers of the protocerebrum by efferent deutoneurons, whose way was being revealed with the Cobalt Chloride 
use (Delabie, 1984). This histochemical procedure has been used to separate projections of the neurons that were joined by means of connections, allowing transynaptic transport of cobalt ions evidencing the route of sensitive cells distributed in neuropile of the thoracic ganglion and of the brain (Pitman et al., 1973; Delabie et al., 1986; Hanesch et al., 1989). Thus, we found that around the middle of the pupal development, glomerulli started to differentiate in the periphery of the antennal lobes progressing to complete the occupation at the end of the pupal development. In the black eyed pupae, optical lobe innervating reached the ommatides (Fig. 8). Each retinulli cell extended to the posterior eye region as an axon crossing the posterior basement lamina for the inner of the optical lobe lamina (Chapman, 1998), what was observed by us just at the end of the pupal development. The brain of an adult individual showed an inverse neuropile and Kenyon cells occupation pattern of that found in the earlier pupal stages, that is, neuropile was the most abundant area in the brain and the glomerulli of the antennal lobes showed their central disposition (Fig. 8).

\section{c) Concluding remarks}

Considering the biological relationships between $A$. octospinosus and A. subterraneus, we suggested that the accommodation of the neurons in the brain during the post-embryonic development caused various morphologic and morphometric changes and pigments accumulation in ommatides according to the respective ages (Fig. 9). However neither all these alterations were proportional, since the area and volume did not show a relationship with the insect age, evidencing a conspicuous plasticity of the brain. This cells accommodation refers to neuroblast proliferation and their specialization in neurons followed by axon and dendrite growth. This phase characterizes a critical period in the development where higher cell division rate occurs (Soares, 2000), corresponding here to brown eyed pupae. The main cell division site in this pupal stage occurs in the concentric regions in the corpora pedunculata calyx (Soares and Serrão, 2001a; 2001b), observed anatomically as small folds in the brain apex (Fig 9). In several insects, neural accommodation occurs by death of nervous cells and glial cells (Cantera, 1993; Kirschenbaum et al., 1995; Sonnenfield and Jacobs, 1995) being suggested the role of juvenile hormone and ecdysteroid in the regulation of this process (Cayre et al., 1994; Restifo et al., 1995). In holometabolous, in the absence of juvenile hormone, ecdysteroid level in haemolymph increase, starting the pupal program. In $M$. sexta higher ecdysteroid level was found in the middle pupal period, coinciding with the dendritics arborization growth of the brain (Chapman, 1998). Thus, analysis of molecular mechanisms involved in the hormonal regulation is a subject to be investigated (Restifo et al., 1995; Levine et al, 1995.). Approaches that show neurons anatomy has been largely used in D. melanogaster (Ito et al., 1998) and are important for the study of information orientation that can be related with memory and learning (Gronenberg et al, 1999; Gronenberg, 2001). More studies on these aspects are necessary, mostly in the Formicidae that has great diversity and the largest behavioral complexity among social insects.

\section{RESUMO}

A neurópila é a região do sistema nervoso central onde ocorrem as sinapses entre as ramificações dos neurônios. Durante o desenvolvimento de um inseto holometábolo pode ocorrer a quebra das fibras dos neurônios formando novos axônios e dendritos e sua distribuição na neurópila do cérebro é organizada de modo a refletir funções específicas do sistema nervoso dos insetos adultos. Os componentes desta organização foram observados e discutidos neste estudo na formiga Acromyrmex octospinosus evidenciando aspectos similares para aqueles descritos para $A$. subterraneus subterraneus, dentre outros insetos para os quais esta informação está disponível.

\section{REFERENCES}

Arnold, G. and Masson, C. (1983), Mise en place des connexions synaptiques de la voie afférente antennaire au cours de développment nymphal de l'ouvrière d'abeille Apis mellifica mellifica. C. $R$. Acad. Sc., 296 : (3), 131-136.

Burrows, M. (1996), The neurobiology of an Insect Brain. Oxford : Oxford University Press.

Cantera, R. (1993), Glial cells in adult and developing prothoracic ganglion of the hawk moth Manduca sexta. Cell Tissue Res., 272, 93-108.

Cayre, M.; Strambi, C. and Strambi, A. (1994), Neurogenesis in an adult insect brain and its hormonal control. Nature. 368, 57-59. 
Chapman, R. F. (1998), The insects: structure and function. In: Nervous System. Cambridge: Cambridge University. pp. 533-569.

Christensen, T. A.; Harrow, I. D.; Cuzzocrea, C.; Randolph, P. W. and Hildebrand, J. G. (1995), Distinct projections of two populations of olfactory receptor axons in the antennal lobe of the sphinx moth Manduca Sexta. Chemical Senses, 20, 313-323.

Delabie, J. H. C. (1984), La Communication Chimique Chez La Fourmi Champignonniste Acromyrmex Octospinosus; Polymorphisme Et Developpement Du Systeme Antennaire. Doctorat Thesis. Troisieme Cycle. Univ. Paris VI.

Delabie, J. H. C.; Masson, C. and Febway, G. (1986), Neurobiological basis of the chemical communication in the fungus-growing ant, Acromyrmex octospinosus. In: Fire ants and leaf-cutting ants. Biology and Management. Boulder : Westview. pp. 302-315.

Fonta, C. (1984), La communication chimique chez la Bourdons (Bombus sp.): une approche neurobiologique pluridisciplinaire. Doctorat de 3è Cycle Entomologie. Université Paris VI.

Gronenberg, W. and Holldobler, B. (1999), Morphologic representation of visual and antenal information in the ant brain. The Journal of Comparative Neurology, 412, 229-240.

Gronenberg, W. (2001), Subdivisions of Hymenopteran mushroom body calyces by their afferent supply. The Journal of Comparative Neurology, 436, 474-489.

Hanesch, U.; Fischbach, K. F. and Heisenberg, M. (1989), Neuronal architecture of the central complex in Drosophila melanogaster. Cell Tiss. Res., 257, 343-366.

Hanson, B. S.; Ljungberg, H.; Hallberg, E. and Lofstedt, C. (1992), Functional specialization of glomeruli in a moth. Science, 256, 1313-1315.

Homberg, U. (1987), Structure and functions of the central complex in insects. In: Gupta, A. P. (ed.). Arthropod Brains. New York : Willey. pp. 347-367.

Ito, K.; Suzuki, K.; Estes P.; Ramaswami, M.; Yamamoto, D. and Strausfeld, N. J. (1998), The organization of extrinsic neurons and their implications in the functional roles of the mushroom bodies in Drosophila melanogaster Meigen. Learning and Memory, 5, 52-77.

Jaffé, K. and Perez, E. (1989), Comparative study of brain morphology in ants. Brain, Behavior and Evolution, 33, 25-33.

Kirschenbaum, S. R.; Higgins, M. R.; Tveten, M. and Tolbert, L. P. (1995), 20-Hydroxyecdisone stimulates proliferation of glial cells inthe developing brain of the moth Manduca Sexta. J. Neurobiol., 28, 234-247.
Levine, R. B. and Truman, J. W. (1982), Metamorphosis of the insect nervous system: changes in the morphology and synaptic interactions of identified neurons. Nature, 299, 250-252.

Levine, R. B.; Morton, D. B. and Restifo, L. L. (1995), Remodeling of the insect nervous system. Current Opinion in Neurobiology, 5, 28-35.

Masson, C. (1970), Mise en evidence, au cours de l'ontogenese d'une fourmi primitive (Mesoponera caffraria F. Smith), d'une proliferation tardive au niveau des cellules globuleuses ("Globulicells") des corps pedoncules. Z. Zellforsch., 106, 220-231.

Mizunami, M.; Iwasaki, M.; Okada, R. and Nishikawa, M. (1998), Topography of modular subunits in the mushroom bodies of the cockroach. The Journal of Comparative Neurology, 399, 153-161.

Pitman, R. M.; Tweedle, C. D. and Cohen, M. J. (1972), Branching of central neurons: intracellular Cobalt injection for light and electron microscopy. Science, 176, 412-414.

Pitman, R. M.; Tweedle, C. D. and Cohen, M. J. (1973), The form of nerves cells: Determination by Cobalt impregnation. In: Intracellular Staining in Neurobiology. Springer Verlag.

Restifo, L. L. (1995), Genetics of ecdysteroid-regulated central nervous system metamorphosis in Drosophila (Diptera: Drosophilidae). Eur. J. Entomology, 92, 169-187.

Soares, P. A. O. (2000), Desenvolvimento do gânglio cerebral de Acromyrmex subterraneus subterraneus Forel 1893 (Hymenoptera; Formicidae; Myrmicinae). Dissertação (Mestrado), Universidade Federal de Viçosa. $80 \mathrm{pp}$.

Soares, P. A. O. and Serrão, J. E. (2001a), Morphometric analysis of the brain in the castes of Acromyrmex subterraneus subterraneus (Hymenoptera, Formicidae) during postembryonic development. Sociobiology, 37 : (3B), 627-632.

Soares, P. A. O. and Serrão, J. E. (2001b), Morphological study of the brain of Acromyrmex subterraneus subterraneus during the postembryonic development. Sociobiology, 38 : (3A), 421-429.

Sonnenfield, M. J. and Jacobs, J. R. (1995), Apoptosis of the midline glia during Drosophila embryogenesis: a correlation with axon contact. Development, 121, 569-578.

Technau, G., Heisenberg, M. (1982), Neural reorganization during metamorphosis of the corpora pedunculata in Drosophila melanogaster. Nature, 295, 405-407.

Vitt, H. and Hartfelder, K. (1998). Neurogenesis detected by BrdU incorporation in brains of larval honeybees, Apis mellifera L. (Hymenoptera; Apidae). International J. Insect Morph. and Embr., 27 : (4), 1-4. 